\title{
DETEKSI MALARIA BERBASIS SEGMENTASI WARNA CITRA DAN PEMBELAJARAN MESIN
}

\author{
Agung W. Setiawan*1, Yusuf A. Rahman ${ }^{2}$, Amir Faisal ${ }^{3}$, Marsudi Siburian ${ }^{4}$, Nova Resfita ${ }^{5}$, Muhammad \\ W. Gifari ${ }^{6}$, Rudi Setiawan ${ }^{7}$
}

${ }^{1}$ Teknik Biomedis, Sekolah Teknik Elektro dan Informatika, Institut Teknologi Bandung, ${ }^{2}$ RSUD Abdul Moeloek, ${ }^{3,4,5,6,7}$ Teknik Biomedis, Jurusan Teknologi Produksi dan Industri, Institut Teknologi Sumatera Email: 'awsetiawan@stei.itb.ac.id, ${ }^{2}$ y.auliarahman@gmail.com, ${ }^{3}$ amir.faisal@bm.itera.ac.id, ${ }^{4}$ marsudi.siburian@bm.itera.ac.id, ${ }^{5}$ nova.resfita@bm.itera.ac.id, ${ }^{6}$ wildan.gifari@bm.itera.ac.id, 7rudi.setiawan@bm.itera.ac.id

"Penulis Korespondensi

(Naskah masuk: 19 November 2020, diterima untuk diterbitkan: 19 Juli 2021)

\begin{abstract}
Abstrak
Di beberapa daerah di Indonesia, malaria masih merupakan salah satu penyakit endemik dan termasuk ke dalam kategori penyakit menular dengan vektor nyamuk Anopheles. Penurunan jumlah mortalitas penderita malaria ini telah menjadi program Pemerintah Indonesia dan World Health Organization. Salah satu hal penting yang dapat dilakukan adalah menyediakan alat diagnosis malaria yang cepat dan akurat berbantukan komputer. Oleh karena itu, pada studi ini dikembangkan sebuah metode deteksi malaria berbasis segmentasi warna citra yang dikombinasikan dengan metode pencacahan objek citra dan pembelajaran mesin berbasis Convolutional Neural Network. Pada studi ini, segmentasi citra dilakukan dengan menetapkan suatu nilai ambas batas tertentu (thresholding) pada model warna HSV. Nilai ambang batas untuk masing-masing kanal warna ditetapkan sebagai berikut: $\mathrm{H}=100-175, \mathrm{~S}=100-250$, dan $\mathrm{V}=60-190$. Terdapat tiga skema pembelajaran mesin yang digunakan, yaitu citra asli menggunakan RMSProp optimizer, citra tersegmentasi menggunakan RMSProp dan Adam optimizer. Akurasi pelatihan dan validasi CNN tertinggi diperoleh dengan skema citra tersegmentasi menggunakan RMSProp optimizer, yaitu sebesar 92,77\% dan 94,38\%. Sementara, deteksi malaria berbasis pencacahan objek memiliki akurasi sebesar 93,78\%. Meskipun deteksi malaria berbasis pencacahan objek memiliki akurasi $93,78 \%$, tetapi sumber daya komputasi dan waktu yang diperlukan jauh lebih rendah.
\end{abstract}

Kata kunci: $C N N$, HSV, malaria, mikroskopis, segmentasi warna

\section{MALARIA DETECTION USING COLOR IMAGE SEGMENTATION AND MACHINE LEARNING}

\begin{abstract}
Malaria is still one of the endemic diseases in several regions of Indonesia. Reducing the malaria mortality rate has become a notable programme, not only does the Government of the Republic of Indonesia project it, but also the World Health Organization has a similar plan to tackle this disease. One of the prominent concerns to properly promote this programme is providing a rapid and accurate malaria diagnosis tool by applying the computer-aided diagnostics to minimize human errors. The aim of this study is to develop a colour microscopic image-based malaria detection using object counting and CNN-based machine learning. In this research, the HSV colour model with threshold values of H: 100-175, S: 100-250, and V: 60-190 was used to remove the image background. There are three machine learning schemes implemented in this study, i.e. original image using RMSProp optimizer, segmented image using RMSProp and Adam optimizer. The highest training and validation accuracy of CNN were obtained using a segmented image scheme by the RMSProp optimizer, 0.9277 and 0.9438. On the contrary, object-based malaria detection has an accuracy of $93.78 \%$. Furthermore, there are several considerations to determine the malaria detection method, i.e. accuracy, computational resources, and time. Even though malaria detection using object counting has an accuracy of $93.78 \%$, lower than the accuracy of CNN validation, the computational resources and time required are much lower and faster. Therefore, this detection method is suitable for smartphone-based devices with low-middle end specifications.
\end{abstract}

Keywords: CNN, color segmentation, microscopic, HSV, malaria 


\section{PENDAHULUAN}

Malaria adalah penyakit tropis yang disebabkan oleh infeksi parasit Plasmodium yang ditularkan melalui gigitan vektor nyamuk Anopheles. Pada tahun 2018 diperkirakan terjadi sekitar 228 juta kasus malaria di seluruh dunia dengan kematian mencapai 405.000 jiwa. (World Health Organization, 2019). Di Indonesia, prevalensi malaria berdasarkan riwayat pemeriksaan darah mengalami penurunan, dari $1,4 \%$ di Tahun 2013 menjadi 0,4\% pada Tahun 2018 (Kemenkes, 2018). Beberapa tantangan dalam menurunkan prevalensi maupun tingkat mortalitas malaria adalah penyediaan alat diagnosis malaria dan peningkatan kapasitas teknis beserta sumber daya manusianya, terutama di daerah rural dengan akses layanan kesehatan yang terbatas (Makanjuola \& TaylorRobinson, 2020), (World Health Organization, 2015).

Pada pasien terduga terjangkit malaria, menemukan parasit malaria pada pemeriksaan mikrosopik hapusan darah tebal masih menjadi gold standard untuk mendiagnosis malaria (Mukry, dkk., 2017). Permasalahan utama dalam diagnosis malaria berbasis citra mikroskopik ini adalah diperlukan sumber daya manusia yang terampil serta berpengalaman (World Health Organization, 2016). Sensitivitas yang rendah (57\%) juga menjadi kendala pemeriksaan mikroskopik (Mfuh, dkk., 2019) Oleh karena itu, diperlukan alat bantu deteksi malaria berbasis citra mikrosopik menggunakan metode diagnostik berbantukan komputer (computer-aided diagnostic) yang dapat digunakan untuk mengurangi kesalahan manusia, terutama akibat kelelahan mata (Rinawati \& Henrika, 2019). Beberapa kelebihan diagnostik berbantukan komputer ini adalah lebih andal dan terstandarisasi, mengurangi beban kerja sehingga dapat melakukan pemeriksaan lebih banyak, serta dapat menurunkan biaya pemeriksanaan (Poostchi, dkk., 2018).

Tujuan utama studi ini adalah melakukan deteksi malaria berbasis citra mikroskopik menggunakan segmentasi warna dan pembelajaran mesin. Disamping itu, juga dilakukan perbandingan kinerja, akurasi deteksi malaria menggunakan penghitungan jumlah deteksi objek pada citra tersegmentasi warna dengan akurasi pembelajaran mesin. Terdapat dua alasan segmentasi warna digunakan pada studi ini, yaitu karakteristik citra yang terdapat parasit malaria dengan yang tidak terinfeksi; warna parasitenya dapat dibedakan dengan jelas. Alasan kedua adalah dalam hal beban komputasi, algoritma segmentasi warna relatif lebih ringan dibandingkan dengan algortima yang lain.

Seiring dengan perkembangan teknologi mobile, telepon pintar dapat digunakan sebagai alat diagnostik berbantukan komputer, terutama untuk deteksi malaria berbasis mikroskopis (Fuhad, dkk., 2020). Salah satu kontribusi yang diharapkan dari studi ini adalah hasil yang telah diperoleh dapat dimanfaatkan untuk melakukan deteksi malaria dengan andal, terjangkau, dan cepat berbasis telepon pintar. Sehingga dapat meningkatkan layanan kesehatan di Indonesia, melalui penurunan angka mortalitas akibat malaria, terutama di daerah rural dengan akses layanan kesehatan yang terbatas.

\section{TINJAUAN PUSTAKA}

\subsection{Segmentasi Citra}

Segmentasi citra merupakan cara pemisahan citra digital menjadi beberapa area berdasarkan perbedaan ciri pada piksel. Segmentasi bertujuan untuk mengekstraksi informasi penting dari suatu citra agar analisis citra menjadi lebih mudah. Pikselpiksel citra ini diberi label dengan karakteristik tertentu seperti warna, intensitas, teksture atau ciri lainnya (Zaitoun, dkk., 2015), (Zhang, dkk., 2018). Segmentasi citra sangat aplikatif pada dunia kedokteran, terutama sebagai analisis yang tepat untuk citra sinar-X, MRI dan mikroskop. Misalnya dalam identifikasi sel kanker, segmentasi citra menjadi teknik utama dan penting dalam pengenalan sel berdasarkan bentuk dan/atau ciri lainnya sehingga pengobatan yang tepat pun dapat dilakukan dengan secepatnya (Kaushik \& Kumar, 2019).

\subsection{Convolution Neural Network}

Pembelajaran mesin merupakan suatu teknik penting di dunia digitisasi dalam pemrosesan citra dan identifikasi objek. Pada segmentasi citra, objek akan diklasifikasikan sesuai dengan ekstraksi ciri dari citra dan memberikan label pada setiap piksel citra tersebut (Kaushik \& Kumar, 2019). CNN merupakan suatu teknik pembelajaran mesin dengan neural network yang sering digunakan untuk pemrosesan citra karena tingginya kinerja sistem dalam klasifikasi dan pengenalan pola pada citra. Dibandingkan dengan metode konvensional, CNN hanya membutuhkan data kemudian memproses dan mengambil keputusan secara otomatis (Sultana, dkk., 2020), (Kaushik \& Kumar, 2019).

Dalam aplikasi pembelajaran mesin berbasis CNN, terdapat beberapa teknik optimasi algoritma yang digunakan, diantaranya Momentum, Root Mean Square Propagation (RMSProp) dan Adaptive Moment Estimation (Adam). Dibandingkan dengan metode lain, Adam merupakan suatu teknik optimasi stokastik yang lebih efisien dan hanya membutuhkan gradien orde satu dengan kebutuhan memori yang kecil (Kingma \& Ba, 2015). Adam merupakan gabungan dari metode AdaGrad dan RMSProp. Metode ini juga sangat cocok dengan data tidak stasioner dan memiliki gradien acak. Sementara itu, RMSProp mempertahankan kecepatan pembelajaran per parameter yang diadaptasi berdasarkan rata-rata nilai gradien terbaru dari suatu bobot, sehingga 
metode ini juga dapat diimplementasikan untuk data nonstasioner (Kingma \& Ba, 2015).

\section{SEGMENTASI WARNA OBJEK}

\subsection{Set Data}

Set data yang digunakan dalam studi ini diperoleh dari Lister Hill National Center for Biomedical Communications, U.S. National Library of Medicine, dan dianotasi secara manual oleh Mahidol-Oxford Tropical Medicine Research Unit di Bangkok, Thailand (Rajaraman, dkk., 2018), (Rajaraman, dkk., 2019). Total citra yang ada di data set ini berjumlah 27.558 yang terbagi menjadi dua kelas dengan jumlah sama rata, yaitu 13.779 untuk kelas terinfeksi dan 13.779 untuk kelas tidak terinfeksi. Detail jumlah data latih dan validasi setiap kelas yang digunakan dalam studi ini dapat dilihat pada Tabel 1 .

\begin{tabular}{ccc}
\multicolumn{3}{c}{ Tabel 1. Set Data } \\
\hline Data & Terinfeksi & $\begin{array}{c}\text { Tidak } \\
\text { Terinfeksi }\end{array}$ \\
\hline Latih & 2.755 & 2.755 \\
Validasi & 11.024 & 11.024 \\
Total & 13.779 & 13.779 \\
\hline
\end{tabular}

\subsection{Penentuan Model Warna dan Ambang Batas}

Set data yang digunakan pada studi memiliki model warna RGB. Untuk menentukan jenis model warna beserta nilai ambang batasnya, maka pada studi ini dibuat suatu montase citra yang tersusun dari 35 citra asli mikroskopi malaria. Pemilihan citra yang akan dimasukkan ke dalam citra montase dilakukan secara acak dengan tetap memperhatikan keterwakilan semua karakteristik citranya. Montase dari citra asli ini dapat dilihat pada Gambar 1. Pada gambar tersebut, dapat dilihat bahwa sel darah merah yang terinfeksi malaria berwarna ungu tua.

Untuk mempermudah penentuan jenis model warna yang akan digunakan, maka montase dari citra asli pada model warna RGB ini direpresentasikan ke dalam histogram 3 Dimensi (3D) yang dapat dilihat pada Gambar 2. Dari Gambar 2 ini terlihat bahwa akan terdapat kesulitan dalam menentukan nilai ambang batas yang digunakan untuk mendeteksi sel darah merah yang terinfeksi malaria di model warna RGB. Oleh karena itu, salah satu alternatif yang dapat digunakan adalah melakukan konversi ke model warna lain.

Pada studi, dipilih model warna HSV yang lebih representatif dan umum digunakan dalam segmentasi citra berbasis warna. Gambar 3 memperlihatkan histogram 3D dari montase citra asli pada model warna HSV. Terlihat bahwa pada model warna ini, warna ungu tua yang merepresentasikan sel darah merah terinfeksi malaria terlihat lebih mengelompok dan terpisah dari warna yang lain. Hal ini akan lebih mempermudah penentuan nilai ambang batas yang akan diimplentasikan untuk melakukan segmentasi warna.

Tabel 2. Nilai Ambang Batas HSV

\begin{tabular}{ccc}
\hline $\begin{array}{c}\text { Komponen } \\
\text { Warna }\end{array}$ & $\begin{array}{c}\text { Batas } \\
\text { Bawah }\end{array}$ & $\begin{array}{c}\text { Batas } \\
\text { Atas }\end{array}$ \\
\hline Hue $(\mathrm{H})$ & 100 & 175 \\
Saturation $(\mathrm{S})$ & 100 & 250 \\
Values $(\mathrm{V})$ & 60 & 190 \\
\hline
\end{tabular}

Penentuan nilai ambang batas komponen $\mathrm{H}, \mathrm{S}$, dan $\mathrm{V}$ pada model warna HSV ditentukan secara manual dengan melihat batas-batas nilai warna ungu tua pada Gambar 3. Pada studi ini, nilai-nilai ambang batas ini belum dapat dilakukan secara otomatis karena kurang seragamnya karakteristik citra yang ada pada data set. Nilai-nilai ambang batas untuk komponen warna $\mathrm{H}, \mathrm{S}$, dan $\mathrm{V}$ yang digunakan pada studi ini dapat dilihat pada Tabel 2. Gambar 4 merupakan hasil segmentasi citra dari Gambar 3 dengan menggunakan nilai-nilai ambang batas pada Tabel 2 .
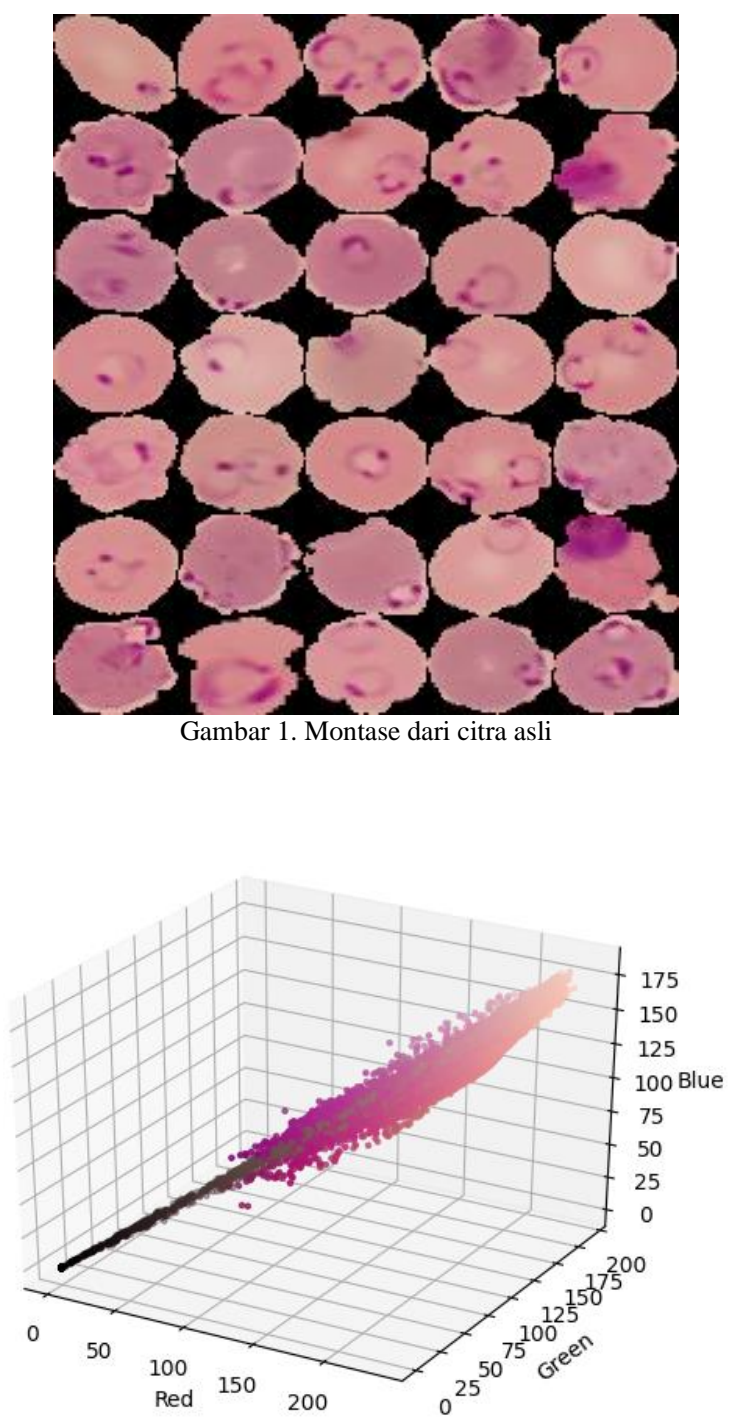

Gambar 2. Histogram 3D dari montase citra asli RGB 


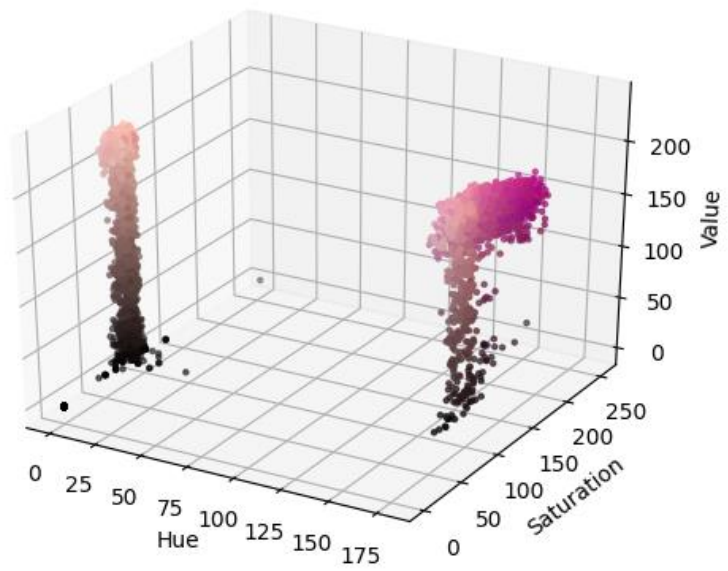

Gambar 3. Histogram 3D dari montase citra HSV

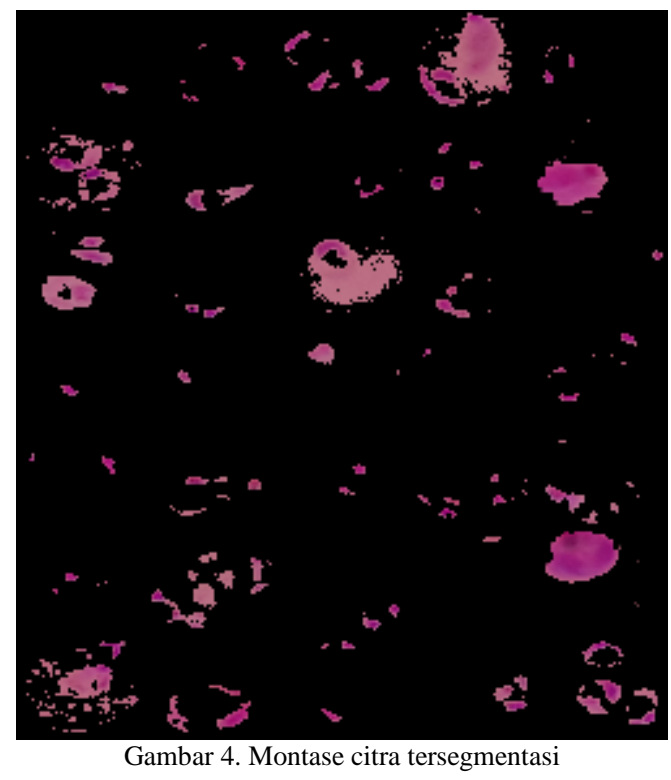

\section{DETEKSI MALARIA}

Pada studi ini, terdapat dua skema deteksi malaria menggunakan citra tersegmentasi warna, yaitu deteksi jumlah objek citra tersegmentasi dan deteksi malaria menggunakan pembelajaran mesin.

\subsection{Akurasi Jumlah Objek Citra Tersegmentasi}

Skema deteksi malaria pertama adalah berdasarkan kemunculan parasite malaria yang terdapat pada citra. Pada studi ini digunakan metode yang cukup sederhana untuk mendeteksi kemunculan parasit malaria pada citra tersegmentasi, yaitu dengan menggunakan algoritma penghitungan objek. Pada algoritma ini, citra warna tersegmentasi diubah menjadi citra abu-abu, kemudian citra tersebut diubah menjadi citra hitam putih. Objek yang terdapat di dalam citra hitam dapat dihitung dengan menggunakan algoritma Object Counting. Gambar 5 memperlihatkan ilustrasi citra asli dan citra tersegmentasi yang disertai dengan jumlah objek yang terdeteksi.

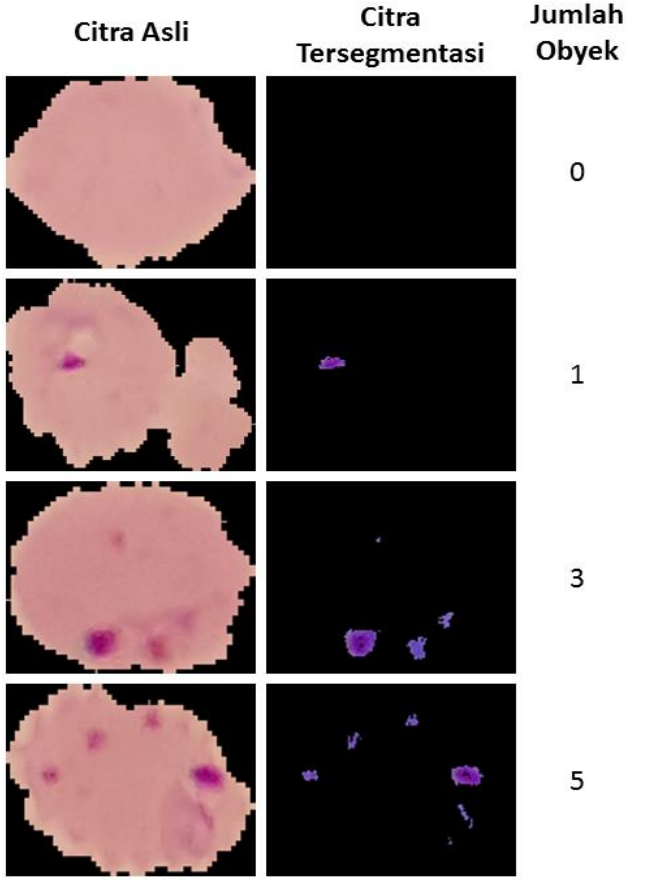

Gambar 5. Ilustasi citra asli, citra tersegmentasi, dan jumlah objek

Hasil penghitungan jumlah objek pada set data yang digunakan dapat dilihat pada confusion matrix yang tersaji dalam Tabel 3. Nilai True Positive (TP), yaitu jumlah citra yang masuk ke kelas terinfeksi dan terdeteksi terinfeksi oleh sistem berbasis jumlah objek, sebesar 12.515. Sementara, nilai True Negative (TN), yaitu jumlah citra yang masuk ke kelas tidak terinfeksi dan terdeteksi tidak terinfeksi oleh sistem berbasis jumlah objek, sebesar 13.328. Formula yang digunakan untuk menghitung nilai akurasi ditunjukkan pada persamaan (1).

$$
\text { Akurasi }=(T P+T N) / \text { Data Total }
$$

Dengan nilai TP dan TN yang diperoleh, maka akurasi sistem deteksi malaria berbasis jumlah objek pada citra tersegmentasi warna pada model HSV ini adalah $93,78 \%$ dengan sensitivitas $90,83 \%$ dan spesifisitas $96,73 \%$.

\subsection{Kinerja Deteksi Pembelajaran Mesin}

Pada studi ini, pembelajaran mesin yang digunakan berbasis Convulotional Neural Network (CNN) yang diimplementasikan dalam Bahasa Python. Arsitektur yang digunakan berbasis VGG16 dan terdapat dua metode optimasi yang diujicobakan pada studi ini, yaitu RMSProp dan Adam Optimizer. Sedangkan parameter kinerja yang digunakan adalah nilai akurasi dan loss.

Terdapat tiga skema implementasi pembelajaran mesin berbasis CNN pada studi ini, yaitu citra asli menggunakan RMSProp optimizer, citra tersegmentasi menggunakan RMSProp 
optimizer, dan citra tersegmentasi menggunakan Adam optimizer.

Tabel 3. Confusion Matrix

\begin{tabular}{cccc}
\hline & & \multicolumn{2}{c}{ Aktual } \\
\cline { 3 - 4 } & & Terinfeksi & Tidak Terinfeksi \\
\hline Pre- & Terinfeksi & 12.515 & 451 \\
diksi & Tidak Terinfeksi & 1.264 & 13.328 \\
\hline
\end{tabular}

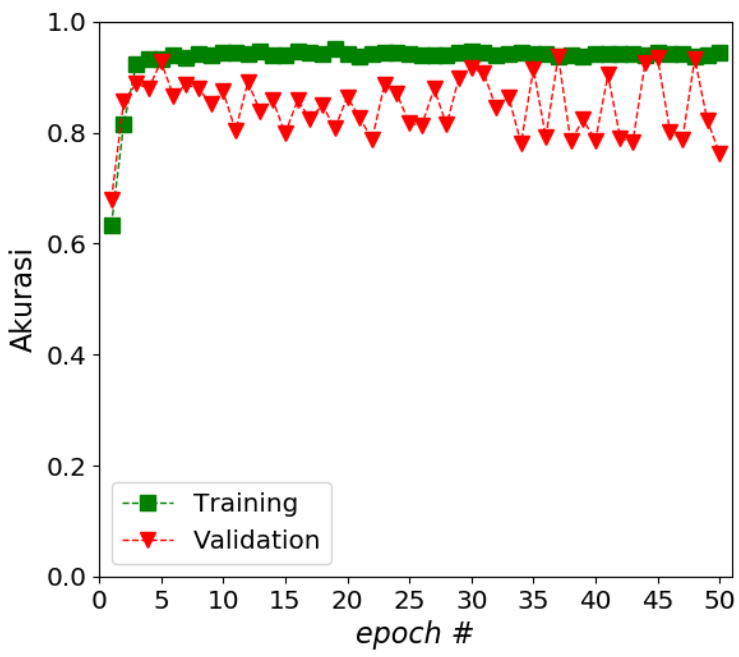

Gambar 6. Akurasi pelatihan dan validasi dari citra asli menggunakan RMSProp optimizer

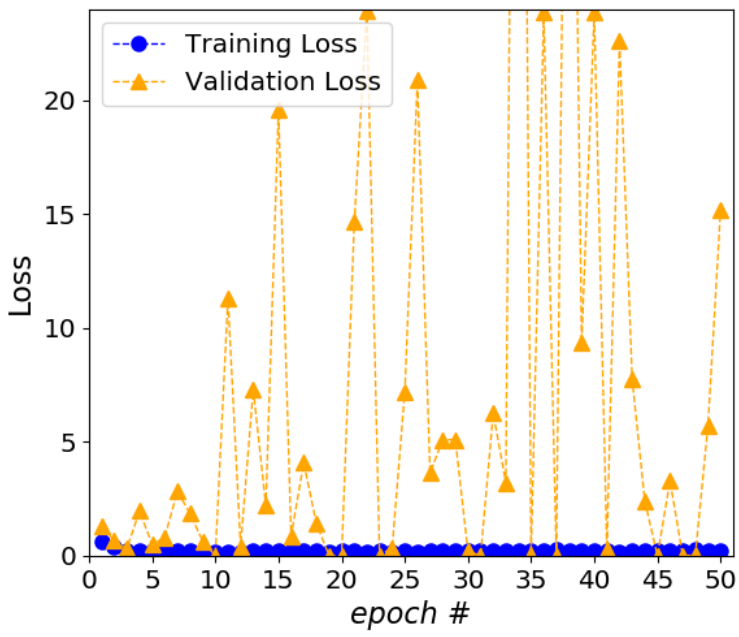

Gambar 7. Loss pelatihan dan validasi dari citra asli menggunakan RMSProp optimizer

Penggunaan citra asli ini digunakan sebagai uji banding dengan citra tersegmentasi. Disamping itu, kedua skema ini digunakan untuk mengetahui kinerja dari proses segmentasi citra berbasis warna pada citra mikroskopi malaria. Grafik akurasi dan loss dari proses pelatihan dan validasi dari citra asli menggunakan RMSProp optimizer ditunjukkan pada Gambar 6 dan Gambar 7. Terlihat bahwa meskipun akurasi pelatihan relatif stabil di sekitar $94 \%$, tetapi nilai akurasi validasi tidak stabil. Pada epoch \#50, nilai akhir yang diperoleh adalah $94,44 \%$ dan $76,21 \%$. Disamping itu, nilai loss pada Gambar 7 memperlihatkan ketidakstabilan proses pembelajaran mesin dengan menggunakan citra asli. Nilai tertinggi loss mencapai lebih dari 24, sementara hasil akhirnya menunjukkan nilai 15,81 .

Hasil akurasi dan loss skema kedua, pembelajaran mesin citra tersegmentasi menggunakan RMSProp optimizer, ditunjukkan pada Gambar 8. Dari epoch \#1 sampai \#50, terlihat bahwa nilai akurasi pelatihan maupun validasi skema ini relatif lebih stabil di sekitar $93 \%$ dan $94 \%$ dengan nilai akhir pada epoch \#50 sebesar $92,77 \%$ dan 94,38\%. Apabila dibandingkan dengan citra asli, nilai loss pembelajaran mesin citra segmentasi menggunakan RMSProp optimizer ini jauh lebih rendah, yaitu sekitar 0,26 untuk pelatihan. Sedangkan grafik loss validasi lebih fluktuatif di sekitar 0,0 - 0.96. Meskipun demikian, pada akhir proses, nilai loss validasi relatif sangat kecil, yaitu 0,0129 serta 0,2634 untuk loss pelatihan.

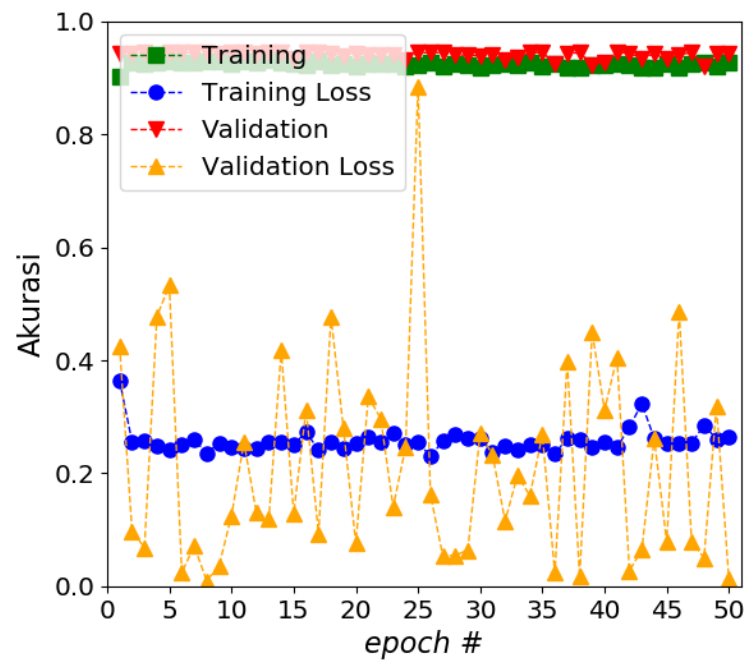

Gambar 8. Akurasi pelatihan dan validasi dari citra tersegmentasi menggunakan RMSProp optimizer

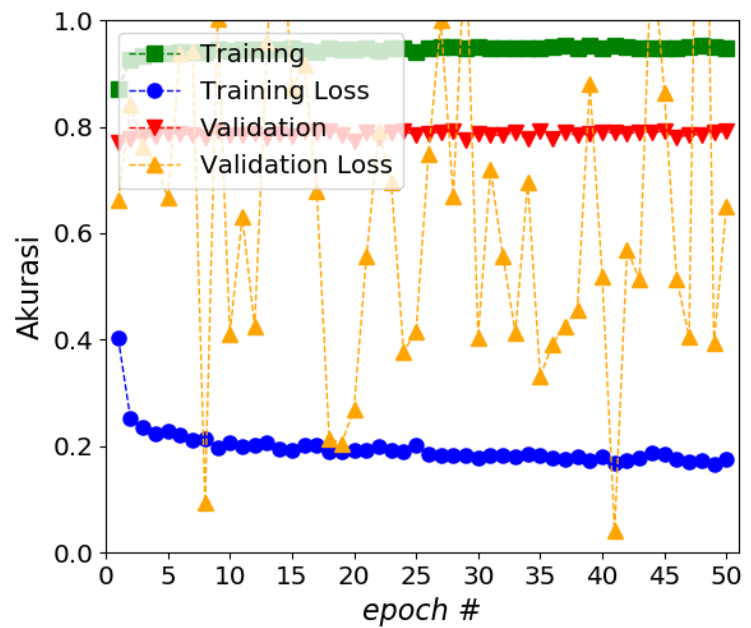

Gambar 9. Akurasi pelatihan dan validasi dari citra tersegmentasi menggunakan Adam optimizer

Hasil akurasi dan loss skema ketiga, pembelajaran mesin citra tersegmentasi menggunakan Adam optimizer, ditunjukkan pada Gambar 9. Tujuan dari skema ketiga ini adalah untuk melihat kinerja dua optimizer yang umum 
digunakan dalam pembelajaran mesin berbasis CNN. Dengan membandingkan grafik pada Gambar 9 dengan Gambar 8, terlihat bahwa pada citra malaria tersegmentasi, kinerja RMSProp lebih baik dibandingkan dengan Adam optimizer. Meskipun nilai akurasi pelatihan di sekitar $95 \%$, akan tetapi nilai akurasi validasinya hanya sekitar $79 \%$. Selain itu, meskipun nilai loss pelatihannya juga lebih rendah dibandingkan dengan skema kedua, yaitu di sekitar 0,18 , tetapi nilai loss validasinya fluktuatif dengan rentang yang lebih lebar, yaitu $0,04-2,03$. Hasil akhir pada epoch \#50 untuk akurasi pelatihan dan validasi, serta loss pelatihan dan validasi adalah $94,81 \% ; 79,09 \%$; $17,65 \%$; dan 64,96\%.

\section{KESIMPULAN}

Dari ketiga skema pembelajaran mesin yang diimplementasikan pada studi ini, skema kedua (citra tersegmentasi menggunakan RMSProp optimizer) memberikan kinerja yang lebih baik. Nilai akurasi, untuk pelatihan maupun validasi, lebih besar dibandingkan dengan dua skema yang lain, yaitu sebesar 92,77\% dan 94,38\%. Disamping itu, nilai loss skema kedua ini juga lebih kecil, yaitu 0,0129 serta 0,2634 . Oleh karena itu, untuk deteksi malaria berbasis citra mikroskopik menggunakan pembelajaran mesin berbasisi CNN, perlu dilakukan preprocessing pada citra mikroskopik malaria berupa penghilangan latar belakang dengan menggunakan segmentasi citra. Pada studi ini, dilakukan segmentasi berbasis warna pada model warna HSV untuk menghilangkan latar belakang citra. Meskipun nilai ambang batas nilai $\mathrm{H}, \mathrm{S}$, dan V dilakukan secara manual berdasarkan citra montase; akurasi dari pencacahan jumlah objek di citra tersegmentasi adalah 93,78\%. Dengan membandingkan akurasi deteksi berbasis pembelajaran mesin skema kedua dan akurasi deteksi berbasis jumlah objek di citra tersegmentasi, perbedaannya sekitar $1 \%$. Pada studi ini terdapat dua trade-off yang perlu menjadi perhatian, yaitu metode deteksi (berbasis pembelajaran mesin atau jumlah objek), waktu, dan beban komputasi. Pada pembelajaran mesin, diperlukan adanya proses pembuatan model, dimana hal ini memerlukan sumber daya komputasi dan waktu yang lebih besar. Sedangkan pada deteksi berbasis jumlah objek, tidak diperlukan adanya waktu tambahan untuk membuat model dan dapat diimplementasikan pada perangkat dengan sumber daya komputasi lebih rendah. Untuk perangkat yang memiliki sumber daya komputasi rendah, misalkan telepon pintar low-middle end dapat menggunakan metode deteksi berbasis jumlah objek.

Deteksi malaria berbasis pencacahan jumlah objek menunjukkan sensitivitas 90,83\%, lebih baik dibandingkan dengan pemeriksaan mikroskopik yang hanya $57 \%$, sehingga memiliki potensi digunakan sebagai alat skrining.
Beberapa rekomendasi yang perlu dilakukan untuk meningkatkan kinerja deteksi malaria menggunakan citra mikroskopik ini adalah perlunya penyeragaman citra pada set data melalui preprocessing. Selain itu, diperlukan mekanisme penentuan nilai ambang batas $\mathrm{H}, \mathrm{S}$, dan V dilakukan secara otomatis dan bersifat adaptif. Pada deteksi objek di citra tersegmentasi, perlu dilakukan kajian penentuan ukuran piksel objek terkecil pada citra. Sehingga objek tersebut masih dapat terhitung.

\section{DAFTAR PUSTAKA}

FUHAD, K.M.F., TUBA, J.F., SARKER, M.R.A., MOMEN, S., MOHAMMED, N. dan RAHMAN, T., 2020. Deep Learning Based Automatic Malaria Parasite Detection from Blood Smear and Its Smartphone Based Application. Diagnostics, [online] 10(5), p.329. Available at: <https://www.mdpi.com/20754418/10/5/329> [Accessed 25 Sep. 2020].

KAUSHIK, R. dan KUMAR, S., 2019. Image Segmentation Using Convolutional Neural Network. International Journal of Scientific and Technology Research, Vol.8, p. 667675.

KEMENKES, R.I., 2018. Laporan Nasional Riskesdas 2018. Jakarta: Kemenkes RI, pp.101-108.

KINGMA, D.P. dan BA, J.L., 2015. Adam: A method for stochastic optimization. In: 3rd International Conference on Learning Representations, ICLR 2015 - Conference Track Proceedings. [online] International Conference on Learning Representations, ICLR. Available at: <https://arxiv.org/abs/1412.6980v9> [Accessed 26 Sep. 2020].

MAKANJUOLA, R.O. dan TAYLOR-ROBINSON, A.W., 2020. Improving Accuracy of Malaria Diagnosis in Underserved Rural and Remote Endemic Areas of Sub-Saharan Africa: A Call to Develop Multiplexing Rapid Diagnostic Tests. Scientifica, Available at: $<$ https://pubmed.ncbi.nlm.nih.gov/3218508 3/> [Accessed 25 Sep. 2020].

MFUH, K.O., ACHONDUH-ATIJEGBE, O.A., BEKINDAKA, O.N., ESEMU, L.F., MBAKOP, C.D., GANDHI, K., LEKE, R.G.F., TAYLOR, D.W. dan NERURKAR, V.R., 2019. A comparison of thick-film microscopy, rapid diagnostic test, and polymerase chain reaction for accurate diagnosis of Plasmodium falciparum malaria. Malaria Journal, [online] 18(1), p.73. Available at: <https://malariajournal.biomedcentral.com/ 
articles/10.1186/s12936-019-2711-4>

[Accessed 26 Sep. 2020].

MUKRY, S.N., SAUD, M., SUFAIDA, G., SHAIKH, K., NAZ, A. dan SHAMSI, T.S., 2017. Laboratory diagnosis of malaria: Comparison of manual and automated diagnostic tests. Canadian Journal of Infectious Diseases and Medical Microbiology, [online] 2017. Available at: <https://pubmed.ncbi.nlm.nih.gov/2847992 2/> [Accessed 25 Sep. 2020].

POOSTCHI, M., SILAMUT, K., MAUDE, R.J., JAEGER, S. dan THOMA, G., 2018. Image analysis and machine learning for detecting malaria. Translational Research, 194, pp.36-55.

RAJARAMAN, S., ANTANI, S.K., POOSTCHI, M., SILAMUT, K., HOSSAIN, M.A., MAUDE, R.J., JAEGER, S. dan THOMA, G.R., 2018. Pre-trained convolutional neural networks as feature extractors toward improved malaria parasite detection in thin blood smear images. PeerJ, [online] 2018(4). Available at <https://pubmed.ncbi.nlm.nih.gov/2968241 1/> [Accessed 25 Sep. 2020].

RAJARAMAN, S., JAEGER, S. dan ANTANI, S.K., 2019. Performance evaluation of deep neural ensembles toward malaria parasite detection in thin-blood smear images. PeerJ, [online] 7, p.e6977. Available at: <https://pubmed.ncbi.nlm.nih.gov/3117918 1/> [Accessed 25 Sep. 2020].

RINAWATI, W. and HENRIKA, F., 2019. Diagnosis Laboratorium Malaria. Journal of The Indonesian Medical Association, 69(10), pp.327-335.

SULTANA, F., SUFIAN, A. dan DUTTA, P., 2020. Evolution of Image Segmentation using Deep Convolutional Neural Network: A Survey. Knowledge-Based Systems, 201202, p.106062.

WORLD HEALTH ORGANIZATION, 2015. Global technical strategy for malaria 20162030. World Health Organization.

WORLD HEALTH ORGANIZATION, 2016. Malaria microscopy quality assurance manual-version 2. World Health Organization.

WORLD HEALTH ORGANIZATION, 2019. World malaria report 2019. World Health Organization.

ZAITOUN, N.M. dan AQEL, M.J., 2015. Survey on Image Segmentation Techniques. In: Procedia Computer Science. Elsevier.pp.797-806.

ZHANG, D., SONG, Y., LIU, D., JIA, H., LIU, S., XIA, Y., HUANG, H. dan CAI, W., 2018.
Panoptic segmentation with an end-to-end cell R-CNN for pathology image analysis. In: Lecture Notes in Computer Science (including subseries Lecture Notes in Artificial Intelligence and Lecture Notes in Bioinformatics). [online] Springer Verlag.pp.237-244. Available at: <https://link.springer.com/chapter/10.1007/ 978-3-030-00934-2_27> [Accessed 26 Sep. 2020]. 
Halaman ini sengaja dikosongkan 